\title{
Hubungan antara Status Gizi dengan Kejadian ISPA pada Anak Usia Toddler (1-3 Tahun)
}

\author{
Ria Rosantia , Feriana Ira Handyana ${ }^{a}$, Agnis Sabat Kristiana ${ }^{a}$ \\ aProdi Sarjana Keperawatan STIKes Maharani Malang, Indonesia \\ E-mail korespondensi: Riaros12@gmail.com
}

\begin{abstract}
Introduction: Nutrition is an important intake that underlies toddler's physical and mental development. Good nutritional status will optimize child development and strengthen the body's immune system, so the risk of developing Acute Respiratory Incidence (ARIs) will also be low. Method: The study is correlation study with cross sectional approach. The study was conducted in March $23^{\text {th }}$ until April 20 ${ }^{\text {th }}$, 2018. The study was located in the working are of Puskesmas Bumiaji, Batu City. Subject were toddlers who visited Puskesmas Bumiaji. The sample were 53 respondents, taken by using purposive sampling technique with total sampling. Data were taken by using ISPA observation sheet and nutritional status was counted by using WHO application: Anthro. Result: Data were analyzed by using Lambda formula. Based on the results of the analysis of nutritional status, it was obtained $p$ value $=0,003$ with $r=1,824$. It stated that there was correlation between nutritional status and the Accute Respiratory Incidence (ARIs) in toddler aged 1-3 years in the work area of Bumiaji clinic Center, Batu City. Low nutritional status can trigger infectious diseases into the body, especially ARI. Conclusion: Toddler age children have a rudimentary physiological body so susceptible to disease if the nutritional status is not in control because it will decrease the immune system. This shows the importance of nutrition for children ages toddler. So that parents, especially mothers, must pay more attention to nutritional adequacy, especially during infancy by consulting directly with the nearest health service and various other references.
\end{abstract}

Keywords: Accute Respiratory Incidence (ARIs), Nutritional status, Toddler

\begin{abstract}
Abstrak
Pendahuluan: Gizi merupakan asupan penting yang mendasari perkembangan fisik dan mental toddler. Status gizi yang baik akan mengoptimalkan perkembangan anak dan memperkuat sistem imunitas tubuh, sehingga resiko terjadinya ISPA juga akan rendah. Metode: Penelitian ini menggunakan metode penelitian correlation study dengan pendekatan cross sectional. Penelitian ini dilakukan pada 23 maret sampai 20 april 2018. Lokasi penelitian di wilayah Kerja Puskesmas Bumiaji Kota Batu. Populasi yang digunakan adalah anak usia toddler yang berkunjung ke Puskesmas Bumiaji. Sampel penelitian diambil dengan menggunakan teknik purposive sampling dengan jumlah 53 responden, Teknik pengambilan data menggunakan lembar observasi ISPA dan status gizi dihitung menggunakan bantuan aplikasi $W H O$ - Anthro. Penelitian dengan metode kuantitatif dengan studi korelasi dengan desain crosssectional. Hasil: Berdasarkan hasil analisis penelitian status gizi didapatkan nilai $\mathrm{p}=0,003$ dengan $\mathrm{r}=1,824$ yang menyatakan terdapat hubungan antara status gizi dengan kejadian ISPA pada anak usia toddler 1-3 Tahun di wilayah kerja Puskesmas Bumiaji Kota Batu. Kesimpulan: Anak usia toddler memiliki fisiologis tubuh yang belum sempurna sehingga mudah terserang penyakit jika status gizi tidak dikontrol karena akan menurunkan sistem kekebalan tubuh. Hal ini menunjukan betapa pentingnya asupan gizi bagi anak usia toddler. Sehingga
\end{abstract}




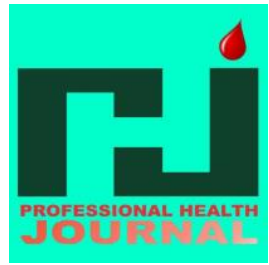

PROFESIONAL HEALTH JOURNAL

Volume 2, No. 1, Desember 2020 (Hal. 38-50)

https://www.ojsstikesbanyuwangi.com/index.php/PHJ

orang tua terutama ibu harus lebih memperhatikan kecukupan gizi, khususnya saat masa balita dengan berkonsultasi langsung pada pelayanan kesehatan terdekat dan berbagai referensi lain.

Kata kunci: ISPA (Infeksi Saluran Pernafasan Akut), Status Gizi, Usia Toddler

\section{PENDAHULUAN}

Salah satu masalah pokok kesehatan di negara sedang berkembang adalah masalah gangguan terhadap kesehatan masyarakat yang disebabkan oleh kekurangan gizi. Penyakit kekurangan gizi banyak ditemui pada masyarakat golongan rentan, yaitu golongan yang mudah sekali menderita akibat kurang gizi dan juga kekurangan zat makanan Kurang Energi dan Protein (KEP) pada anak masih menjadi salah satu masalah gizi dan kesehatan masyarakat di Indonesia. Pada tahun 2014 masalah gizi kurang di Indonesia masih merupakan masalah kesehatan masyarakat mendekati prevalensi tinggi. Diantara 33 provinsi, terdapat tiga provinsi yang termasuk dalam kategori status gizi kurang dengan prevalensi sangat tinggi, yaitu Sulawesi Barat sebesar 22,1\% dari 466.185 anak, Nusa Tenggara Timur sebesar $21,5 \%$ dari 474.378 anak dan Nusa Tenggara Barat sebesar $19,4 \%$ dari 495.185 anak (Kemenkes RI, 2015).

ISPA merupakan salah satu gangguan kesehatan yang sangat penting dikarenakan menjadi penyebab utama kematian terutama di negara berkembang. Infeksi saluran pernapasan akut disebabkan oleh virus atau bakteri. Penyakit ini diawali dengan panas disertai salah satu atau lebih gejala: tenggorokan sakit atau nyeri telan, pilek, batuk kering atau berdahak. Di Indonesia periode prevalensi ISPA dihitung dalam kurun waktu 1 bulan Rosanti, Ria, dkk., Status Gizi ISPA Toddler... terakhir. Lima provinsi dengan ISPA tertinggi adalah Nusa Tenggara Timur $(41,7 \%)$, Papua $(31,1 \%)$, Aceh $(30,0 \%)$, Nusa Tenggara Barat $(28,3 \%)$, dan Jawa Timur (28,3\%). Pada Riskesdas 2007, Nusa Tenggara Timur juga merupakan provinsi tertinggi dengan ISPA. Periode prevalensi ISPA Indonesia menurut Riskesdas 2013 (25,0\%) tidak jauh berbeda dengan 2007 (25,5\%) (Riskesdas, 2013).

Status gizi pada masa toddler perlu mendapatkan perhatian serius karena jika teajadi kurang gizi pada masa ini dapat menyebabkan kerusan irreversible (tidak dapat dipulihkan). Kekurangan gizi yang lebih fatal akan berdampak pada perkembangan otak, karena perkembanagn otak yang pesat terjadi saat usia 30 minggu - 18 bulan. Gizi sangat berpengaruh terhadap nafsu makan selain itu infeksi dapat menghambat reaksi imunilogis dengan menghabiskan energi tubuh , apabila anak terkena defisiensi status gizi, maka anak akan rentan terkena penyakit infeksi salah satunya adalah ISPA yang sangat rentan terjadi pada anak usia toddler. Status gizi toddler dapat diketahui dengan mencocokan antara tinggi badan dengan berat badan standar pedoman WHO-NCHS, sedangkan parameter yang

digunakan untuk Balita adalah berat badan dan tinggi badan (Marni, 2014).

Kasus ISPA di Kota Batu masih menduduki peringkat pertama dalam 
PROFESIONAL HEALTH JOURNAL

Volume 2, No. 1, Desember 2020 (Hal. 38-50)

https://www.ojsstikesbanyuwangi.com/index.php/PHJ

jumlah kasus penyakit yang dilayani di fasilitas pelayanan kesehatan dasar (Puskesmas). Dari data tersebut, ISPA merupakan penyakit yang tergolong penyakit menular. Hal ini menggambarkan adanya beban ganda dalam penanganan masalah kesehatan masyarakat di Kota Batu, dimana jumlah kasus penyakit menular masih tinggi. Dalam data Dinas Kesehatan Kota Batu, menyebutkan bahwa angka kejadian ISPA pada tahun 2014 tertinggi mencapai 18.622 jiwa dan menjadi penyebab kematian tertinggi (Dinkes Batu, 2014).

Hasil studi pendahuluan yang dilakukan oleh peneliti pada bulan Oktober 2017 di Puskesmas Bumiaji Kec. Bumiaji, Kota Batu. Masih tingginya angka kejadian ISPA di Desa Bumiaji. Jumlah kejadian ISPA pada anak balita berada di peringkat kedua dalam jumlah kejadian ISPA terbesar menurut umur dengan nilai kejadian hingga 1222 kasus dalam rentang 1 tahun terakhir. Sedangkan dalam 3 bulan terakhir (periode bulan Juli - September 2017) jumlah angka kejadian ISPA pada anak usia Balita mencapai 126 kasus, dan usia toddler (1-3 tahun) mencapai angka 49 kasus. Dan di sisi lain, masih tingginya angka Balita BGM dengan jumlah 40 kasus dalam 3 bulan terakhir. Melihat tingginya angka kejadian ISPA dan Balita BGM, maka peneliti tertarik melakukan penelitian tentang hubungan antara status gizi dengan kejadian ISPA pada anak usia

toddler (1 - 3 tahun) di Puskesmas Bumiaji Kota Batu (Dinkes Batu, 2014).

Sebagian besar bayi usia $6-12$ bulan yang memiliki status gizi normal Rosanti, Ria, dkk., Status Gizi ISPA Toddler... berada dalam kategori jenis kelamin perempuan, berat badan lahir rendah, status imunisasi belum lengkap, riwayat pemberian ASI non eksklusif, dan belum mendapat vitamin A (Christi \& Rahayuning, 2015) Menurut Badan Kesehatan Dunia (WHO) pemberian ASI ekslusif dilakukan untuk menghindari alergi dan menjamin kesehatan bayi secara optimal. Karena di usia ini, bayi belum memiliki enzim pencernaan sempurna untuk mencerna makanan atau minuman lain (Habibi, Gayatri, \& Bantas, 2016).

\section{METODE}

Sesuai dengan tujuan penelitian, maka jenis penelitian ini adalah studi korelasi dengan desain penelitian cross sectional.

Populasi dari penelitian ini adalah anak usia toddler (1-3 tahun) yang sedang registrasi di Puskesmas Bumiaji sebanyak 53 anak. Sampel yang dilakukan dengan cara purposive sampling sesuai dengan kriteria inklusi yaitu pasangan ibu dan anak usia toddler (1-3 tahun) dan anak yang terdaftar registrasi di Puskesmas Bumiaji. Dalam penelitian ini kriteria eksklusi dari responden adalah anak dengan status imunisasi tidak lengkap dan Anak dengan BBLR. Dengan status gizi sebagai variabel independent (variabel bebas) dan kejadian ISPA sebagai variabel dependent (variabel terikat).

Instrumen yang digunakan berupa standart deviasi unit (Z-Score) dan bantuan aplikasi WHO - Anthr, timbangan digital merk tesena, bagi bayi yang belum nbisa 
PROFESIONAL HEALTH JOURNAL

Volume 2, No. 1, Desember 2020 (Hal. 38-50)

https://www.ojsstikesbanyuwangi.com/index.php/PHJ

berjalan menggunakan timbangan manual merk focal. Serta pedoman observasi dan indikator MTBS untuk memperoleh data dan diagnosis ISPA. Dalam pengujian validitas terhadap kuesioner, penelitian ini menggunakan validitas diukur bila item yang disusun menggunakan lebih dari satu faktor (antara faktor satu dengan yang lain ada kesamaan). Pengukuran validitas faktor ini dengan cara mengkorelasikan antara skor faktor (penjumlahan item dalam satu faktor) dengan skor total faktor (total keseluruhan faktor).

Pada penelitian ini, pengolahan untuk data status gizi menggunakan bantuan aplikasi WHO-Anthro dengan anthropometric calculator. Data yang dibutuhkan yakni meliputi tanggal pemeriksaan, jenis kelamin, tanggal lahir anak, berat badan $(\mathrm{kg})$, tinggi badan $(\mathrm{cm})$, cara pengukuran dengan berdiri kemudian melihat hasil Z-Score yang sudah tertera di anthropometric calculator.

Setelah data terkumpul selanjutnya melakukan analisis. Analisis univariate yang dilakukan menganalisis tiap variabel dari hasil penelitian untuk meringkas kumpulan data hasil pengukuran sehingga kumpulan data tersebut berubah menjadi informasi yang berguna. Analisis Bivariate secara simultan dari dua variabel. Hal ini dilakukan untuk melihat apakah satu variabel terkait dengan variabel lain yang mungkin memiliki kesetaraan. Penelitian terhadap dua variabel disini mempunyai tujuan untuk

mendiskripsikan distribusi data, meguji perbedaan dan mengukur hubungan antara dua variabel yang diteliti yakni status gizi dan kejadian ISPA.

Rosanti, Ria, dkk., Status Gizi ISPA Toddler...
Penelitian ini menggunakan metode penelitian kuantitatif dengan studi korelasi (Correlation study) yaitu jenis penelitian yang digunakan untuk mempelajari dinamika korelasi antara faktor resiko dengan efek, desain penelitian yang digunakan dalam penelitian ini adalah cross sectional, yaitu faktor resiko dan efek yang terjadi pada subjek penelitian diukur secara simultan atau sekaligus dalam waktu yang bersamaan. Pada hakikatnya penelitian ini merupakan penelitian hubungan antara dua variabel pada suatu situasi atau sekelompok subjek.

\section{HASIL PENELITIAN}

Tabel 1. Distribusi Usia Responden

\begin{tabular}{ccc}
\hline Usia (Tahun) & $\begin{array}{c}\text { Frekuensi } \\
(\mathrm{F})\end{array}$ & $\begin{array}{c}\text { Persentase } \\
(\%)\end{array}$ \\
\hline$<2$ & 22 & 41,5 \\
$>2$ & 31 & 58,5 \\
\hline Jumlah & 53 & 100 \\
\hline
\end{tabular}

Berdasarkan tabel 1 dapat disimpulkan bahwa dari 53 responden usia 1-3 tahun di Puskesmas Bumiaji Kota Batu ditemukan sebagian besar berusia $>2$ tahun sebanyak 31 anak $(58,5 \%)$.

Tabel 2. Distribusi Jenis Kelamin Responden

\begin{tabular}{ccc}
\hline $\begin{array}{c}\text { Jenis } \\
\text { Kelamin }\end{array}$ & Frekuensi (F) & $\begin{array}{c}\text { Persentase } \\
(\%)\end{array}$ \\
\hline Laki-laki & 20 & 37,7 \\
Perempuan & 33 & 62,3 \\
\hline Jumlah & 53 & 100 \\
\hline
\end{tabular}

Berdasarkan tabel 2 dapat disimpulkan bahwa dari 53 responden usia 1-3 tahun di Puskesmas Bumiaji Kota Batu ditemukan sebagian besar dengan jenis 
PROFESIONAL HEALTH JOURNAL

Volume 2, No. 1, Desember 2020 (Hal. 38-50)

https://www.ojsstikesbanyuwangi.com/index.php/PHJ

kelamin perempuan sebanyak 33 anak $(62,3 \%)$

Tabel 3. Distribusi Status Gizi Responden

\begin{tabular}{ccc}
\hline Status Gizi & Frekuensi (F) & $\begin{array}{c}\text { Persentase } \\
(\%)\end{array}$ \\
\hline Sangat Kurus & 2 & 3,8 \\
Kurus & 24 & 45,3 \\
Normal & 26 & 49,1 \\
Gemuk & 1 & 1,9 \\
\hline Jumlah & 53 & 100 \\
\hline
\end{tabular}

Berdasarkan tabel 3 dapat disimpulkan bahwa dari 53 responden usia 1-3 tahun di Puskesmas Bumiaji Kota Batu ditemukan hampir seterngah dari responden dengan status gizi normal sebanyak 26 anak $(49,1 \%)$.

Tabel 4. Distribusi Kejadian ISPA pada Responden

\begin{tabular}{ccc}
\hline $\begin{array}{c}\text { Kejadian } \\
\text { ISPA }\end{array}$ & $\begin{array}{c}\text { Frekuensi } \\
(\mathrm{F})\end{array}$ & $\begin{array}{c}\text { Persentase } \\
(\%)\end{array}$ \\
\hline ISPA & 27 & 50,9 \\
Tidak ISPA & 26 & 49,1 \\
\hline Jumlah & 53 & 100 \\
\hline
\end{tabular}

Berdasarkan tabel 4 dapat disimpulkan bahwa dari 53 responden usia 1-3 tahun di Puskesmas Bumiaji Kota Batu ditemukan sebagian besar dengan status ISPA sebanyak 27 anak $(50,9 \%)$.

Tabel 5. Uji Kolmogorov Sminorv Test

\begin{tabular}{cccccccc}
\hline \multirow{2}{*}{$\begin{array}{c}\text { Status } \\
\text { Gizi }\end{array}$} & \multicolumn{4}{c}{ Kejadian ISPA } & \multirow{2}{*}{ Total } \\
\cline { 2 - 5 } & \multicolumn{2}{c}{ ISPA } & \multicolumn{3}{c}{ Tidak ISPA } & & \\
\cline { 2 - 5 } Sangat & 2 & 3,8 & 0 & 0 & & 2 & 3,8 \\
Kurus & & & & & & \\
& & & & & & \\
Kurus & 19 & 35,8 & 5 & 9,4 & & 24 & 45,3 \\
Normal & 6 & 11,3 & 20 & 37,7 & 26 & 49,1 \\
Gemuk & 0 & 0 & 1 & 1,9 & & 1 & 1,9 \\
\hline Jumlah & 27 & 50,9 & 26 & 49,1 & 53 & 100 \\
\hline
\end{tabular}

Rosanti, Ria, dkk., Status Gizi ISPA Toddler...
Berdasarkan tabel 5 uji Kolmogorov Sminorv test dapat disimpulkan bahwa dari 53 responden usia 1-3 tahun di Puskesmas Bumiaji Kota Batu ditemukan sebagian besar dengan status gizi kurus dengan ISPA sebanyak 35,8\% dan status gizi normal tidak ISPA sebanyak $37,7 \%$.

Analisa data dilakukan dengan menggunakan Uji Kolmogorov - Smirnov Test. Sebelum dilakukan pengujian, berikut disajikan tabel silang untuk menjelaskan hubungan variabel-variabel tersebut secara deskriptif.

Tabel 6. Uji Normalitas dengan Kejadian ISPA Kolmogorov - Smirnov Test

$\begin{array}{ll}\text { Status gizi } & \mathrm{r}=1,824 \\ & \mathrm{p}=0,003 \\ \mathrm{n} & =53\end{array}$

Berdasarkan tabel 6 uji normalitas dengan Kolmogorov - Smirnov Test diperoleh nilai KSZ sebesar 1,824 dan nilai signifikansi didapatkan sebesar 0,003 maka dapat disimpulkan bahwa data tidak berdistribusi normal.

\section{PEMBAHASAN}

\section{Status Gizi Pada Anak Usia Toddler (1-3 Tahun)}

Berdasarkan hasil penelitian dijelaskan bahwa dari 53 anak dengan status gizi normal lebih besar dan sebagian kecil adalah dengan status gizi kurus.

Penurunan gizi lebih banyak terjadi pada anak umur 2 tahun. Hal ini disebabkan karena usia toddler khususnya 1-2 tahun identik dengan perkembangan fisiologi 
PROFESIONAL HEALTH JOURNAL

Volume 2, No. 1, Desember 2020 (Hal. 38-50)

https://www.ojsstikesbanyuwangi.com/index.php/PHJ

tubuh yang belum optimal dan membutuhkan gizi yang cukup. Asupan makan dan minum yang sedikit menyebabkan status gizinya tidak seimbang. Anak usia 2 tahun asupan makan anak umur dibawah 36 bulan berbeda dengan anak maupun dewasa. Anak dibawah usia 36 bulan memerlukan karbohidrat dengan bantuan amilase untuk mencerna bahan makanan yang berasal dari zat pati. Protein yang diperlukan dari ASI ibu yaitu dengan kadar 4-5 dari total kalori dalam ASI, lemak yang diperlukan sebanyak setengah dari kalori total dalam susu matur. Mineral yang diperlukan pada masa ini terdiri dari kalsium, pospor, klor, kalium dan natrium yang menunjang pertumbuhan dan perkebangan anak.

Pertumbuhan yang baik dan status gizi yang memadai akan menghasilkan tingkat kesehatan yang baik pula. Sebaliknya, pertumbuhan fisik yang terhambat biasanya anak mudah terkena penyakit (kurangnya asupan makanan di dalam tubuh berdampak mengakibatkan kurang gizi yang dapat menurunkan daya tahan tubuh. Berikan anak berbagai jenis buah dan sayuran, kacang - kacangan serta daging tanpa lemak untuk mendukung sistem imunitas. Yoghurt yang banyak mengandung bakteri berguna yang disebut probiotik, juga dapat membantu tubuh melawan penyakit seperti pilek, infeksi telinga dan radang tenggorokan. Susu sapi juga sangat baik bagi sistem imunitas anak-anak karena tidak hanya mengandung kalsium, tapi juga protein,

vitamin A dan beberapa jenis vitamin B. Sebelum menentukan porsi makan anak, maka perlu mengetahui dahulu berapa banyak kalori yang dibutuhkan anak. Rosanti, Ria, dkk., Status Gizi ISPA Toddler...
Menurut Angka Kecukupan Gizi (AKG) Indonesia tahun 2013, anak usia 2-3 tahun membutuhkan 1125 kilo kalori.

Pada keadaan biasa MP-ASI dibuat dari makanan pokok yang disiapkan secara khusus dan diberikan 3-5 kali sehari sebelum anak usia 24 bulan, ASI harus tetap diberikan secara teratur dan sering. Untuk menghitung kecukupan energi individu dapat dilakukan dengan menghitung jumlah pengeluaran energi total selama satu hari. Pengeluaran energy total terdiri dari pengeluaran energi saat istirahat (REE) atau Basal Metabolic Rate (BMR) yang merupakan jumlah minimum energi yang dibutuhkan untuk melakukan proses - proses tubuh vital. Dimana tanpa berlangsungnya kegiatan tersebut tidak mungkin terjadi kehidupan (Proverawati \& Kusumawati, 2011).

Menu seimbang yang dibutuhkan anak toddler adalah konsumsi garam tidak lebih dari $1 / 6$ jumlah maksimum orang dewasa sehari atau kurang dari 1 gr, cermati karena makanan anak usia toddler tidak sama dengan orang dewasa, biasanya orang dewasa mengkonsumsi banyak gula dan banyak garam yang artinya banyak bahan pengawet dan bahan pewarna buatan. Porsi makan anak juga tidak sama dengan orang dewasa, mereka membutuhkan makanan dengan sumber energi yang lengkap gizi dalam jumlah lebih kecil namun sering. Bahan makanan yang paling dibutuhkan adalah sumber energi seperti karbohidrat, protein, lemak serta vitamin, mineral dan serat wajib

dikonsumsi anak setiap hari. Susu merupakan sumber kalsium sehingga penting pula bagi anak usia toddler sedikitnya membutuhkan $350 \mathrm{ml}$ per hari. 
PROFESIONAL HEALTH JOURNAL

Volume 2, No. 1, Desember 2020 (Hal. 38-50)

https://www.ojsstikesbanyuwangi.com/index.php/PHJ

Susu pertumbuhan merupakan susu lengkap gizi yang mampu memenuhi kebutuhan nutrisi anak usia 12 bulan keatas (Proverawati \& Kusumawati, 2011).

Status gizi pada masa toddler perlu mendapatkan perhatian serius dari orangtua karena kekurangan gizi pada masa ini akan menyebabkan kerusakan yang irreversible atau kerusakan yang tidak bisa dipulihkan. Ukuran tubuh yang pendek dapat menjadi salah satu indikator kekurangan gizi yang berkepanjangan pada toddler. Kekurangan gizi yang lebih fatal akan berdampak pada perkembangan otak. Karena fase perkembangan otak sangat pesat pada usia 30 minggu 18 bulan. Parameter yang cocok digunakan untuk toddler adalah berat badan, tinggi badan dan lingkar kepala. Lingkar kepala digunakan untuk memberikan gambaran tentang perkembangan otak. Kekurangan gizi akan berpengaruh terhadap perkembangan fisik dan mental anak (Alboneh, 2013).

Status gizi kurus seringkali ditemukan pada balita dengan gejala pucat, cepat pusing, nafsu makan menurun, tidak bertenaga dan sesak nafas. Meningkatnya kebutuhan tubuh akan zat besi pada masa pertumbuhan dan kurangnya intake zat besi dari makanan seperti ikan, daging, hati dan sayuran hijau tua serta meningkatnya pengeluaran zat besi dari tubuh menyebabkan ketidakseimbangan antara zat gizi yang diperlukan dengan zat gizi yang didapat sehingga tubuh mengambil

dari makanan cadangan lain seperti jaringan lemak oleh karena itu secara fisik akan terlihat kurus dan mengalami penurunan berat badan (Siagian, 2010).
Malnutrisi lazim pada orang dewasa yang sakit kritis dan anakanak. Nutrisi yang buruk dikaitkan dengan pernafasan yang lebih buruk, fungsi otot pernafasan dapat mempengaruhi peningkatan kerentanan terhadap infeksi dan mortalitas. Akibatnya, banyak peneliti yang minat menyelidiki apakah mengoptimalkan nutrisi dalam ISPA dapat menyebabkan peningkatan hasil klinis (Loi, Wang, Ong, \& Hau, 2017)

\section{Kejadian ISPA Pada Anak Usia Toddler (1-3 Tahun)}

Berdasarkan hasil dilapangan dari 53 responden didapatkan bahwa pada kejadian ISPA adalah termasuk dalam kategori cukup banyak yakni 50,9\%. Hal ini berarti bahwa di desa Bumiaji kejadian ISPA dalam rentang cukup banyak. Berdasarkan analisis anak dengan ISPA. Hal tersebut utamanya disebabkan karena anak usia toddler masih belum memiliki sistem imun yang kuat atau masih berada dalam masa pembentukan sehingga secara fisiologi masih belum optimal karena imunitas belum berfungsi dengan baik.

Pada umumnya,infeksi saluran pernapasan akut dapat dibagi menjadi infeksi yang dominan mempengaruhi saluran pernapasan bagian atas dan saluran pernapasan bawah. Secara anatomis, pita suara berfungsi sebagai garis pemisah antara dua daerah ini dengan wilayah atas saluran ratory (nasofaring, struktur peritonsil, sinus, laring, dan epiglotis) menjadi proksimal dari kabel dan saluran

pernapasan bagian atas bawah (pohon bronkial dan paru parenchyma) berada di bawah tali (Rogan \& Misercordiae, 2017). 
PROFESIONAL HEALTH JOURNAL

Volume 2, No. 1, Desember 2020 (Hal. 38-50)

Masuknya virus sebagai antigen kedalam saluran pernafasan menyebabkan silia yang terdapat pada permukaan saluran nafas bergerak keatas mendorong virus kearah faring atau dengan suatu tangkapan refleks spasmus oleh laring. Jika reflek tersebut gagal maka virus merusak lapisan epitel dan lapisan mukosa saluran pernafasan. Iritasi virus pada dua lapisan tersebut menyebabkan timbulnya batuk kerin. Kerusakan struktur lapisan dinding saluran pernafasan mengakibatkan naiknya aktivitas kelenjar mucus yang banyak terdapat pada dinding saluran pernafasan sehingga menyebabkan keluarnya cairan mukosa yang melebihi normal. virus dengan potensi tinggi penularan pada populasi anak yang tidak memiliki antibodi dengan reaktivitas silang yang bisa menyebabkan pembentukan immunecomplex dan penyakit paru-paru yang parah (Nascimento et al., 2018).

Rangsangan cairan yang berlebihan tersebut menimbulkan gejala batuk, sehingga pada awal gejala ISPA yang menonjol adalah gejala batuk. Adanya infeksi virus merupakan predisposisi terjadinya infeksi sekunder bakteri. Akibat infeksi virus tersebut terjadi kerusakan mekanisme mukosiliaris yang merupakan mekanisme perlindungan pada saluran haemophylus influenza dan staphylococcus menyerang mukosa yang rusak tersebut. Infeksi bakteri ini menyebabkan sekresi muskus bertambah banyak dan dapat menyumbat saluran nafas sehingga timbul gejala sulit nafas bahkan sesak nafas dan juga menyebabkan batuk yang produktif.

Invasi bakteri ini dipermudah dengan adanya faktor seperti malnutrisi. Virus menyerang saluran nafas dan menyebar Rosanti, Ria, dkk., Status Gizi ISPA Toddler...
Ke seluruh tubuh ke tempat lain sehingga dapat timbul gejala demam dan mungkin hingga kejang dan juga bisa menyebar ke saluran nafas bawah, sehingga bakteri yang biasanya hanya ditemukan pada saluran pernafasan atas, sesudah terjadinya infeksi virus dapat menginfeksi paru-paru sehingga menyebabkan pneumonia (Sofia, 2017).

Kondisi fisik rumah yang berkategori kurang, kondisi ventilasi kamar tidur balita, pencahayaan kamar tidur balita, tingkat pencemaran udara dalam rumah yang berkategori tinggi dan paparan asap rokok dalam rumah mempunyai pengaruh terhadap kejadian ISPA. Perumahan yang baik terdiri dari kumpulan rumah yang dilengkapi dengan berbagai fasilitas pendukungnya seperti sarana jalan, saluran air kotor, tempat sampah, sumber air bersih dan dekat dengan pusat kesehatan masyarakat. Lokasi perumahan harus bebas banjir sesuai standar arsitektur bangunan perumahan umum. Pada dasarnya ditujukan untuk menyediakan rumah tinggal yang cukup baik dalam bentuk desain, letak dan luas ruangan serta fasilitas lainnya agar dapat memenuhi persyaratan rumah tinggal yang sehat dan menyenangkan. Kondisi rumah yang buruk memungkingkan terjadinya penularan penyakit termasuk penyakit saluran pernapasan seperti ISPA. Kurangnya pencahayaan, terlalu lembab, ventilasi yang buruk, kepadatan penghuni dan letak dapur merupakan beberapa kondisi rumah yang buruk dan mendukung tumbuhnya

bakteri penyakit dan berpengaruh terhadap terjadinya penyakit infeksi pernapasan karena pencahayaan yang kurang dapat 
PROFESIONAL HEALTH JOURNAL

Volume 2, No. 1, Desember 2020 (Hal. 38-50)

https://www.ojsstikesbanyuwangi.com/index.php/PHJ

memperpanjang masa hidup kuman dalam droplet nuklei di udara. Baru-baru ini terdapat penelitin bahwa klasifikasi penyakit lebih banyak mengarah ke perawatan ISPA. Banyak dari penelitian ini berfokus pada diferensiasi antara bakteri, virus, dan penyakit tidak menular di Indonesia yakni pasien dengan imunokompeten (Ross, Zick, \& Tsalik, 2019).

Sejak 1993, bukti menunjukkan bahwa sebagian besar anak balita di Ghana menderita ISPA. Penelitian ini berusaha untuk menguji prevalensi gejala ISPA pada balita lintas zona ekologis serta faktor anak dan ibu yang terkait dengan ISPA sejak 1993 hingga 2014. Penelitian ini menggunakan data dari Survei Demografi dan Kesehatan Ghana (19932014). Sampel penelitian termasuk wanita dari usia reproduksi yang memiliki anak balita dengan gejala batuk disertai nafas pendek yang cepat dalam dua minggu terakhir sebelum survei dilaksanakan (Seidu, Kwabena, Opoku, Baatiema, \& Appiah, 2019).

\section{Hubungan Antara Status Gizi Dengan Kejadian ISPA Pada Anak Usia Toddler (1-3 Tahun)}

Anak dengan status gizi kurang atau kurus jauh lebih beresiko terjadinya ISPA. Pada penelitian ini dibuktikan dengan responden penelitian anak usia toddler yang mengalami ISPA sebanyak $35,8 \%$ anak adalah dengan status gizi kurus dan sebanyak $37,7 \%$ adalah anak yang tidak mengalami ISPA dengan status

gizi normal. Hal ini sejalan dengan penelitian hasil penelitian dari (Mariza \& Trisnawati, 2015) mengungkapkan bahwa Rosanti, Ria, dkk., Status Gizi ISPA Toddler... dapat diketahui dari responden ada hubungan status gizi dengan terjadinya ISPA pada bayi di Wilayah Kerja Puskesmas Rajabasa Indah tahun 2013. Bahwa responden dengan kategori status gizi kurang berpeluang terkena ISPA

Anak yang keadaan gizinya kurang akan mudah mengalami penyakit infeksi, karena kurangnya asupan energi dan protein yang tidak mencukupi kebutuhan, sehingga pembuatan zat antibodi terganggu. Sistem kekebalan tubuh atau imunitas adalah suatu sistem pertahanan tubuh digunakan untuk melindungi tubuh dari infeksi penyakit atau kuman. Penyakit atau kuman ini berupa protein asing yang berbeda dari protein tubuh kita, yang sering disebut antigen. Karena disebut sesuatu yang asing maka antigen ini harus dinetralisir. Yang bertugas melakukan ini salah satunya adalah sistem pertahanan tubuh yang dikenal dengan antibodi. Antibodi adalah suatu zat yang dibentuk tubuh ayang berasal dari protein darah jenis gama-globulin dan berfungsi untuk melawan antigen yang masuk tubuh. Umumnya yang bertugas melawan antigen adalah sel darah putih atau leukosit (Habibi et al., 2016)

Sistem kekebalan tubuh ada secara alami dan buatan, secara buatan adalah suatu bentuk kekebalan tubuh yang sengaja dibuat atau ditumbuhkan melalui pemberian vaksin. Vaksin adalah bibit penyakit atau antigen yang telah dilemahkan. Dan proses pemberian vaksin kedalam tubuh disebut vaksinasi. Salah satu cara lain untuk menumbuhkan

kekebalan pada tubuh adalah dengan menyuntikan serum yang merupakan plasma darah yang mengandung antibodi 
PROFESIONAL HEALTH JOURNAL

Volume 2, No. 1, Desember 2020 (Hal. 38-50)

https://www.ojsstikesbanyuwangi.com/index.php/PHJ

tertentu untuk melawan antigen tertentu.

Sistem imunitas merupakan hasil kerjasama dari rangkaian sel, jaringan, protein dan organ tubuh (Sofia, 2017)

Proses imunitas dibentuk sejak awal kehidupan, dan akan terus berkembang seiring dengan pertambahan usia. anak usia toddler sudah mendapat dukungan sistem imunitas sejak bayi melalui air susu ibu (ASI) yang pertama kali keluar mengandung kolostrum. Kolostrum mengandung immunoglobulin A (IgA) yang mampu melindungi tubuh dari kuman. Caranya dengan membentuk jaringan pelindung pada usus, hidung, dan tenggorokan. Saat mendapatkan asupan ASI maka anak juga memperoleh antibodi dan faktor pelindung kuman lain dari tubuh ibunya (Mariza \& Trisnawati, 2015).

Kedua hal inilah yang memperkuat sistem imunitas. Secara umum, rendahnya imunitas dapat menyebabkan terganggunya proses tumbuh kembang anak, yang mungkin disertai dengan penyakit paru paru. Sistem imunitas tergantung pada apa yang dimasukan kedalam perut sehingga penting menjaga asupan nutrisi yang dapat mendukung sistem imunitas tersebut. Studi membuktikan bahwa kondisi malnutrisi kemungkinan lebih rentan terkena infeksi. Terdapat beberapa asupan nutrisi yang dianggap penting untuk sistem imunitas. Misalnya vitamin A akan membantu menghindari infeksi dan menjaga jaringan mukosa. Selain itu, vitamin B2 dan B6 berguna untuk meningkatkan resistensi bakteri dan mencegah penurunan respon sistem imunitas. Peran vitamin $\mathrm{C}$ hingga

kini masih diteliti, namun diduga mampu mendukung nutrisi lain untuk meningkatkan sistem imunitas. Sementara Rosanti, Ria, dkk., Status Gizi ISPA Toddler... itu, vitamin D diketahui mampu berfungsi sebagai antimikroba pada tuberculosis. Dua mineral yang tidak kalah penting untuk sistem imunitas yaitu zinc dan selenium. Zinc berkaitan langsung dengan fungsi sel sistem imunitas. Sementara kekurangan selenium dikaitkan dengan resiko kandung kemih dan paru - paru (Mariza \& Trisnawati, 2015).

Menurut peneliti, pada anak yang mengalami kurang gizi pada tingkat ringan atau sedang masih dapat beraktifitas,tetapi bila diamati dengan seksama badannya akan mulai kurus, stamina dan daya tahan tubuhnya pun menurun, sehingga mempermudah untuk terjadinya penyakit infeksi, sebaliknya anak yang menderita penyakit infeksi akan mengalami gangguan nafsu makan dan penyerapan zat-zat gizi sehingga menyebabkan kurang gizi. Namun dari penelitian ini ditemukan juga responden yang berstatus gizi baik tetapi terkena ISPA. Hal ini mungkin disebabkan oleh faktor lain yang dapat menyebabkan terjadinya ISPA pada anak usia toddler seperti umur, pemberian ASI, keteraturan pemberian vitamin A, polusi udara, sosial ekonomi, imunisasi kepadatan dalam rumah dan BBLR. Selain itu didapatkan juga responden yang berstatus gizi kurang tetapi tidak terkena ISPA. Hal tersebut bisa terjadi kemungkinan karena faktor lingkungan tempat tinggalnya yang tidak ada yang menderita ISPA meskipun status gizinya kurang, atau bisa dikarenakan mereka sudah mendapatkan imunisasi yang lengkap sehingga mereka mempunyai kekebalan tubuh terhadap serangan infeksi

sehingga tidak mudah terkena ISPA. Dari hasil diatas dapat disimpulkan bahwa gizi mempunyai peran yang sangat besar dalam 
PROFESIONAL HEALTH JOURNAL

Volume 2, No. 1, Desember 2020 (Hal. 38-50)

https://www.ojsstikesbanyuwangi.com/index.php/PHJ

pemeliharaan kesehatan tubuh anak usia toddler. Jika anak mengalami status gizi yang kurang maka akan lebih mempermudah kuman maupun bakteri patogen menyerang tubuh sehingga terjadi ISPA. Maka dari itu untuk mengurangi angka kejadian ISPA maka status gizi balita harus selalu dijaga dan ditingkatkan.

\section{KESIMPULAN DAN SARAN}

Berdasarkan pada hasil analis dapat diambil beberapa kesimpulan sebagai berikut: Status gizi responden menunjukan bahwa dari 53 responden usia 1-3 tahun di Puskesmas Bumiaji Kota Batu ditemukan hampir setengah dari responden dengan status gizi normal sebanyak 26 anak $(49,1 \%) ; 2$. Kejadian ISPA menunjukan dari 53 responden usia 1-3 tahun di Puskesmas Bumiaji Kota Batu ditemukan sebagian besar dengan status ISPA sebanyak 27 anak $(50,9 \%)$; 3. Terdapat hubungan antara status gizi dengan kejadian ISPA pada anak usia toddler (1-3 tahun) di wilayah kerja Puskesmas Bumiaji Kota Batu.

Kondisi sosial seperti lingkungan dan gizi yang buruk dianggap dapat meningkatkan paparan agen infeksi dan penurunan resistensi inang terhadap infeksi. Fasilitas perawatan kesehatan seperti imunisasi, menyusui dan suplementasi vitamin A.

Berdasarkan rangkaian proses penelitian yang telah dilakukan, dapat memberikan saran sebagai berikut:

Disarankan bagi ibu balita untuk lebih memperhatikan kecukupan gizi, khususnya saat masa-masa balita dengan berkonsultasi langsung pada pelayanan kesehatan terdekat dan berbagai referensi lain. Dengan tercukupinya kebutuhan gizi balita, maka sistem imun akan berkembang optimal dan menurunkan resiko terjadinya ISPA dan penyakit lainnya terutama infeksi. Hal ini bisa menjadi panduan untuk para orang tua untuk memenuhi kebutuhan gizi balita khususnya anak usia 1-3 tahun untuk mencegah terjadinya berbagai penyakit termasuk ISPA salah satunya; Disarankan bagi petugas kesehatan hendaknya meningkatkan kualitas pelayanan, penyuluhan dan pendidikan kesehatan terhadap masyarakat khususnya orang tua yang mempunyai balita sehingga setiap balita terhindar dari segala jenis penyakit khususnya ISPA dan mendapat asupan gizi cukup agar terhindar dari berbagai penyakit dan tercipta balita yang sehat dan cerdas; Disarankan bagi peneliti untuk memperluas lingkup penelitian, meneliti faktor lain terkait faktior resiko ISPA seperti faktor lingkungan, suhu, kelembaban dan sikap ibu. Sehingga nantinya akan memperkaya informasi yang sangat dibutuhkan oleh masyarakat terkait resiko ISPA pada balita. Balita dengan status gizi baik yang mengalami ISPA mempunyai persentase kecil, hal ini kemungkinan disebabkan karena daya tahan tubuh yang baik, ventilasi rumah yang baik. Balita yang mendapat pola asuh gizi yang baik yaitu mendapat makanan cukup baik dan seimbang, daya tahan tubuh.

\section{DAFTAR PUSTAKA}

Christi, H., \& Rahayuning, D. (2015). Faktor - faktor yang berhubungan 
PROFESIONAL HEALTH JOURNAL

Volume 2, No. 1, Desember 2020 (Hal. 38-50)

https://www.ojsstikesbanyuwangi.com/index.php/PHJ

dengan kejadian ISPA pada bayi usia 6-12 bulan yang memiliki status gizi normal, 3(April).

Dinkes Batu. (2014). Profil Kesehatan Kota Batu Tahun 2014.

Habibi, M., Gayatri, D., \& Bantas, K. (2016). Faktor-faktor yang Mempengaruhi Kejadian Infeksi Saluran Pernapasan Akut ( ISPA ) pada Anak Berumur 12-59 Bulan di Puskesmas Kelurahan Tebet Barat , Kecamatan Tebet, Jakarta Selatan , Tahun 2013, 1(1), 23-27.

Kemenkes RI. (2015). Profil Kesehatan Indonesia 2014. Jakarta. Retrieved from

http://www.kemkes.go.id

Loi, M., Wang, J., Ong, C., \& Hau, J. (2017). Nutritional support of critically ill adults and children with acute respiratory distress syndrome: A clinical review. Clinical Nutrition ESPEN.

https://doi.org/10.1016/j.clnesp.2017.0 2.005

Mariza, A., \& Trisnawati. (2015). Faktorfaktor Yang Berhubungan Dengan Terjadinya Ispa Pada Bayi (1-12 Bulan) Di Wilayah Kerja Puskesmas Rajabasa Indah Bandar Lampung Tahun 2013, 1(2), 57-62.

Marni. (2014). Asuhan Keperawatan Pada Anak Dengan Gangguan Pernapasan. (D. Dermawan, Ed.). Yogyakarta: Gosyen Publishing.

Nascimento, L., Canela, P., Magalhãesbarbosa, M. C. De, Eduardo, C., Carney, S., Mendonca, M., ... Alves, Rosanti, Ria, dkk., Status Gizi ISPA Toddler...
L. (2018). Viral detection profile in children with severe acute respiratory infection. Brazilian Journal of Infectious Diseases, 22(5), 402-411. https://doi.org/10.1016/j.bjid.2018.09.0 01

Nazrul, S., Kamal, M., \& Rahmatullah, R. (2018). Serum zinc levels in children with acute respiratory infections: Association with sociodemography and nutritional status. Clinical Nutrition Experimental, 22, 11-18. https://doi.org/10.1016/j.yclnex.2018.0 9.002

Proverawati, A., \& Kusumawati, E. (2011). Ilmu Gizi untuk Keperawatan \& Gizi Kesehatan (2nd ed.). Yogyakarta: Mulia Medika.

Riskesdas. (2013). Riset Kesehatan Dasar (RISKESDAS) 2013. Laporan Nasional 2013, 1-384. https://doi.org/1 Desember 2013

Rogan, M., \& Misercordiae, M. (2017). Respiratory Infections, Acute. International Encyclopedia of Public Health, Second Edition (Second Edition, Vol. 6). Elsevier. https://doi.org/10.1016/B978-0-12803678-5.00383-0

Ross, M. H., Zick, B. L., \& Tsalik, E. L. (2019). Host-Based Diagnostics w for Acute Respiratory Infections. Clinical Therapeutics, 41(10), 1923-1938. https://doi.org/10.1016/j.clinthera.2019 .06 .007

Seidu, A., Kwabena, E., Opoku, B., Baatiema, L., \& Appiah, F. (2019). 
PROFESIONAL HEALTH JOURNAL

Volume 2, No. 1, Desember 2020 (Hal. 38-50)

https://www.ojsstikesbanyuwangi.com/index.php/PHJ

Ecological zone and symptoms of acute respiratory infection among children under five in Ghana : 1993 2014. SSM - Population Health, 8(May), 100414. https://doi.org/10.1016/j.ssmph.2019.1 00414
Siagian, A. (2010). Epidemiologi Gizi. (R. Astikawati, Ed.). Erlangga.

Sofia. (2017). Faktor Risiko Lingkungan Dengan Kejadian Ispa Pada Kabupaten Aceh Besar ( Environmental Risk Factors For The Incidence Of ARI In Infants In The Working Area Of The Community Health Center Ingin Jaya District Of Aceh Besar ), 2(1), 43-50. 